\title{
Estrogen and progesterone play pivotal roles in endothelial progenitor cell proliferation
}

\author{
Yuko Matsubara and Keiichi Matsubara ${ }^{*+}$
}

\begin{abstract}
Background: It has been previously suggested that angiogenesis occurs during the menstrual cycle. Moreover, a rise in uterine blood flow is largely maintained by vasodilatation and substantial increases in angiogenesis. It is known that estradiol (E2) and progesterone (P4) are involved in angiogenesis. Recently, endothelial progenitor cells (EPCS) were found to be involved in neovascularization; however, their roles in uterine neovascularization have not been well characterized. We hypothesized that E2- or P4-mediated EPC proliferation plays important roles in uterine neovascularization during the menstrual cycle.
\end{abstract}

Methods: The number of EPCs in peripheral blood from subjects in the menstrual phase $(n=12)$, follicular phase $(n=8)$, and luteal phase $(n=16)$, was measured using flow cytometry. Peripheral blood mononuclear cells (PBMCs) were cultured for seven days with or without 17beta-estradiol (E2beta) or P4, followed by assessment of EPC proliferation based upon the uptake of acetylated low density lipoprotein (LDL) and lectin. The expression of estrogen receptor (ER) or progesterone receptor (PR) in EPCs was also evaluated using real-time PCR.

Results: E2beta and P4 significantly increased the proliferation of EPCs derived from the peripheral blood of subjects in menstrual phase, but not subjects in the luteal phase. In addition, the expression level of ERalpha was markedly higher than ERbeta in EPCs derived from women in menstrual phase.

Conclusions: EPC proliferation is induced during the menstrual phase and proliferation can be affected by estrogen through ERalpha activation.

Keywords: menstrual cycle, neovascularization, ovarian hormones

\section{Background}

Angiogenesis in female reproductive organs, including the uterus, corpus luteum, and placenta, is essential for implantation and is critical for the dramatic (30-50 fold) elevation of uterine blood flow during pregnancy $[1,2]$. Disturbances in uterine vascular development are associated with pregnancy loss, preeclampsia, and intrauterine growth restriction [3]. Periodic uterine endometrial neovascularization begins after menstruation and continues into the luteal phase [4]. In general, it is thought that neovascularization is mainly caused by angiogenesis, which is the sprouting of capillaries from pre-existing vessels, such as in tumors and embryos. However, vasculogenesis, which is mediated by endothelial progenitor

\footnotetext{
*Correspondence: keiichi@m.ehime-u.ac.jp

+ Contributed equally

Department of Obstetrics and Gynecology, Ehime Prefectural Niihama Hospital, Hongo, Niihama, Ehime, 792-0042 Japan
}

cells (EPCs), has recently been proposed to be involved in endometrial neovascularization $[5,6]$. The presence of EPCs in peripheral blood provides a maintenance reservoir of endothelial cells (ECs) and contributes to up to $25 \%$ of ECs in newly formed vessels [7]. It has been hypothesized that EPCs may be involved in the growth of the uterine endometrium since EPCs localize within the vasculature and stroma of the uterine endometrium and myometrium after ovulation [8].

In female reproductive organs, neovascularization may be partially regulated by cyclic changes in sex steroids, such as estradiol $\left(E_{2}\right)$ and progesterone $\left(P_{4}\right)[9,10]$ in response to the hormones produced by the hypothalamus, pituitary gland, and ovaries [11]. Serum $\mathrm{E}_{2}$ and $\mathrm{P}_{4}$ concentrations are very low during the early follicular phase [12]. During this phase, serum estrogen levels rise in parallel to the growth of follicle size and granulosa cells. Before ovulation, follicle-produced $\mathrm{E}_{2}$ is increased

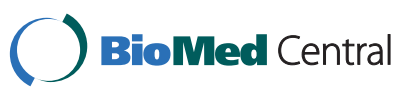


and luteinization of the granulosa cells is stimulated, which leads to the synthesis of $\mathrm{P}_{4}$. After ovulation, the granulosa cells continue to enlarge and become lutein. The corpus luteum, which consists of luteinized granulosa cells and theca-lutein cells, secretes $\mathrm{P}_{4}$. There is a secondary rise in $\mathrm{E}_{2}$ levels during the mid-luteal phase following a decrease before menstruation, and this rise in $\mathrm{E}_{2}$ levels occurs in parallel with the rise of serum $\mathrm{P}_{4}$ levels. However, the effects of these hormones and their interactions in reproductive organs remain unclear, especially in vasculogenesis.

Estrogen receptors (ERs) are expressed in uterine arterial ECs $[13,14]$, as well as in other types of ECs [15], which suggests that $17 \beta$-estradiol $\left(\mathrm{E}_{2} \beta\right)$ can act directly on the cells and alter uterine vascular function. It has been reported that $E_{2} \beta$ can enhance angiogenesis $[16,17]$ and vasculogenesis by increasing the number of EPCs [18]. These data support the theory that $E_{2} \beta$ is an important factor in promoting neovascularization in female reproductive organs. Similar to $\mathrm{E}_{2} \beta, \mathrm{P}_{4}$ has also been shown to influence uterine angiogenesis [19]. $P_{4}$ may enhance $E_{2} \beta$-induced angiogenesis by increasing endothelial nitric oxide synthase (eNOS) expression [20]. In contrast, it has been reported that $\mathrm{P}_{4}$ inhibits $\mathrm{E}_{2} \beta$-reduced neointimal proliferation [21] and decreases ER and $\mathrm{P}_{4}$ receptor (PR) expression in human uterine vascular endothelium [22], which consequently attenuates $\mathrm{E}_{2} \beta$-induced angiogenic responses [23,24].

The aim of this study was to evaluate the influence of sex steroids on the proliferation of EPCs during the menstrual cycle. The findings of this study could help elucidate the role of vasculogenesis in cyclic endometrial neovascularization.

\section{Methods}

\section{EPC isolation}

This study was approved by the Ehime University Institutional Review Board. All participants gave informed consent for participation in this study. Peripheral venous blood $(20 \mathrm{ml})$ from healthy young volunteers in the menstrual phase $(\mathrm{n}=12 ; 30 \pm 4$ years-old $)$, follicular phase $(\mathrm{n}=8 ; 30 \pm 5$ years-old $)$, luteal phase $(\mathrm{n}=16 ; 28$ \pm 4 years-old) with regular menstrual cycles $(24-35 \mathrm{~d}$ ) was collected in tubes containing sodium heparin. The menstrual cycle dates were determined by measuring the basal body temperature (BBT) as reported by the patient and serum $E_{2}$ (follicular phase $>10 \mathrm{pg} / \mathrm{ml}$ ) and progesterone (follicular phase $<1.5 \mathrm{ng} / \mathrm{ml}$; luteal phase $>5.7 \mathrm{ng} / \mathrm{ml}$ ) concentrations. The follicular phase is characterized by a lower BBT [11]. Peripheral blood mononuclear cells (PBMCs) were isolated by density gradient centrifugation at $1600 \mathrm{rpm}$ for $60 \mathrm{~min}$ with Ficoll-Paque separating solution (Amersham Pharmacia Biotech; AB, Uppsala, Sweden). The PBMC layer was collected, cells were counted, and then a fraction of the cells was resuspended in Dulbecco's phosphate-buffered saline (D-PBS: Invitrogen; Carlsbad, CA) with 1\% fetal bovine serum (FBS: Invitrogen) for fluorescence-activated cell sorting (FACS) analysis. Circulating EPCs (cEPCs) were characterized by the expression of vascular endothelial growth factor receptor 2 (VEGF-R2; kinase domain receptor $[K D R]), A C 133$, and CD34 on the surface of PBMCs.

To assess the proliferation of EPCs, the cells were cultivated according to a previously described technique [25]. Briefly, PBMCs $\left(8 \times 10^{5}\right.$ cells $)$ were seeded into each well of 96-well culture plates coated with human fibronectin (Sigma-Aldrich, St. Louis, MO) and cultured in endothelial basal medium-2 (EBM-2, Clonetics; San Diego, CA) supplemented with EGM-2MV (Clonetics) consisting of $5 \%$ FBS, VEGF, fibroblast growth factor-2 (FGF2), epidermal growth factor (EGF), insulin-like growth factor-1 (IGF1), and ascorbic acid. After four days in culture, nonadherent cells were removed and adherent cells were subsequently cultured for an additional three days.

\section{Low density lipoprotein (LDL)/lectin assay}

After seven days in culture, adherent cells were assessed as EPCs based on the uptake of 1,1'-dioctadecyl-3,3,3',3'tetramethylindocarbocyanine-labeled acetylated LDL (Dil-Ac-LDL, Biogenesis; Poole, UK) and FITC-labeled Ulex europaeus agglutinin I (FITC-lectin, SigmaAldrich). Cells were incubated with Dil-Ac-LDL $(2.4 \mu \mathrm{g} /$ $\mathrm{ml}$ ) for one hour at $37^{\circ} \mathrm{C}$ and fixed with $2 \%$ paraformaldehyde for $10 \mathrm{~min}$. Cells were washed twice with DPBS and then incubated with FITC-lectin $(10 \mu \mathrm{g} / \mathrm{ml})$ for one hour at $37^{\circ} \mathrm{C}$. Cells were washed twice with DPBS and detached with $0.25 \%$ trypsin/EDTA.

\section{FACS analysis}

Before culturing the cells, the cEPCs were confirmed by FACS with a PE-labeled monoclonal antibody against human KDR (Genzyme Techne; Cambridge, MA), a FITC-labeled monoclonal antibody against human AC133 (Genzyme Techne), and a PerCP-labeled monoclonal antibody against human CD34 (Becton Dickinson). Then, $1.0 \times 10^{5} \mathrm{PBMCs}$ were incubated with the three antibodies for $30 \mathrm{~min}$ at $4^{\circ} \mathrm{C}$ in the dark. Isotype antibodies were used as controls. After incubation, cells were analyzed with a FACScan flow cytometer (Becton Dickinson) and Cell Quest software (Becton Dickinson) (Figure 1). On the 7th day of culture, adherent cells were incubated with Dil-acLDL and FITC-lectin, and double-stained cells were analyzed by FACS (Figure 2).

\section{EPC culture with $E_{2} \beta$ or $P_{4}$}

To assess the effects of $E_{2} \beta$ or $\mathrm{P}_{4}$ on EPC proliferation of EPCs, $8 \times 10^{5}$ PBMCs, derived from the peripheral 

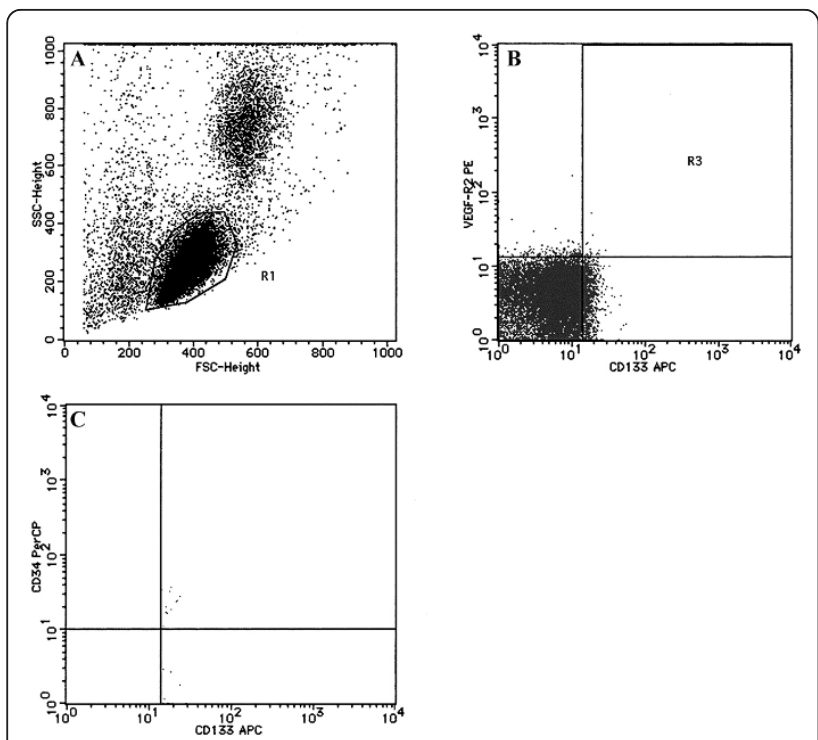

Figure 1 Characterization of circulating EPCs from peripheral blood. A) The mononuclear cell fraction was selected based on low granularity by forward and side scatter using FACS. B, C) Sorted cells were fixed and immunostained with antibodies against human KDR, AC133, and CD34, and then subjected to FACS analysis.

blood of women in the menstrual or luteal phases, were seeded into each well of 96-well culture plates coated with human fibronectin (Sigma-Aldrich), and cultured in endothelial basal medium (phenol red free EBM-2, Clonetics; San Diego, CA) supplemented with EGM$2 \mathrm{MV}$ (Clonetics) consisting of $5 \%$ charcoal stripped serum (Invitrogen), VEGF, FGF2, EGF, IGF1, and ascorbic acid with or without $10^{-9}-10^{-7} \mathrm{M}$ of $\mathrm{E}_{2} \beta$ or $\mathrm{P}_{4}$. ICI $182,780\left(10^{-5} \mathrm{M}\right.$, Wako Pure Chemical Industries, Ltd.,

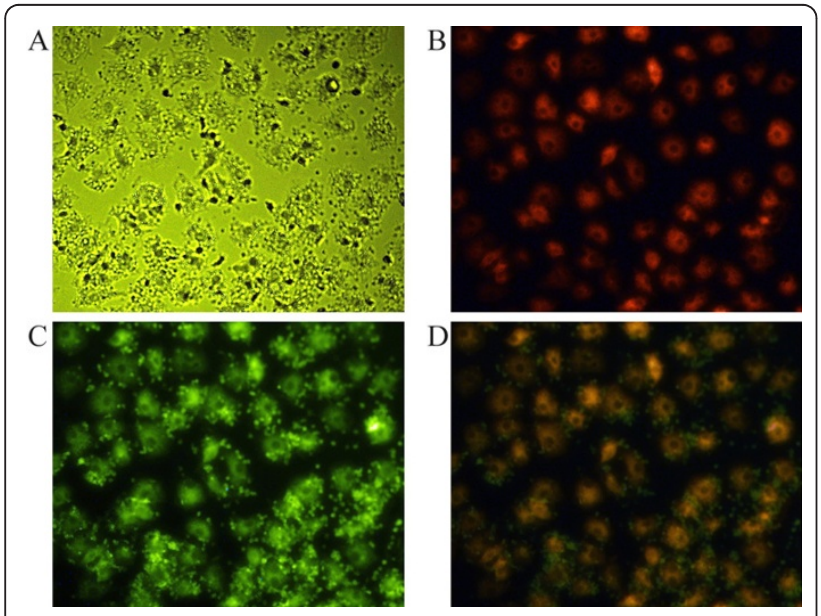

Figure 2 LDL/lectin assay to detect EPCs in culture. A) Cultivated PBMCs were examined using Dil-Ac-LDL/FITC-lectin uptake assays. B) Live EPCs exposed to Dil-AcLDL and C) stained with FITC-lectin (Ulex europeaus) D) Merged images $(40 \times$ final magnification).
Osaka, Japan) or RU486 (10 ${ }^{-5} \mathrm{M}$, Sigma-Aldrich) was used as an inhibitor of ER or PR, respectively [26]. After four days in culture, nonadherent cells were removed and adherent cells were subsequently cultured for an additional three days.

\section{Isolation of RNA and semi-quantitative RT-PCR}

Total RNA was collected from cells grown in $3.5 \mathrm{~cm}$ cell culture dishes. Cells were washed with cold DPBS and subsequently frozen at $-80^{\circ} \mathrm{C}$ until isolation of total RNA. The cells were disrupted and homogenized with an ultrasound homogenizer. Total RNA was extracted using the RNeasy Mini Kit (QIAGEN; Valencia, CA) according to the manufacturer's instructions. Total RNA $(2 \mu \mathrm{g})$ was reverse transcribed to cDNA by incubating the samples with a random primer $(100 \mathrm{pmol} / \mu \mathrm{l})$ at $70^{\circ} \mathrm{C}$ for $10 \mathrm{~min}$, followed by $4^{\circ} \mathrm{C}$ for $10 \mathrm{~min}$. The samples were then incubated with Tris$\mathrm{HCl}$ (pH 8.3), $75 \mathrm{mM} \mathrm{KCl}, 3 \mathrm{mM} \mathrm{MgCl}, 10 \mathrm{mM}$ DTT, 2.5 $\mathrm{mM}$ dNTPs, ribonuclease inhibitor (40 U/ $\lambda$ Promega Corp. Madison, WI), AMV reverse transcriptase XL (37 U/ $\lambda$ Takara Biochemicals Tokyo, Japan), and a dNTP mixture $(2.5 \mathrm{mM})$ and then incubated at $42^{\circ} \mathrm{C}$ for one hour. The samples were subsequently heated at $99^{\circ} \mathrm{C}$ for $5 \mathrm{~min}$ to terminate the reaction, and stored at $4^{\circ} \mathrm{C}$.

$\mathrm{ER} \alpha, \mathrm{ER} \beta$, progesterone receptor $\mathrm{AB}$ (PR $\mathrm{AB})$, progesterone receptor $\mathrm{B}$ (PR B), and glyceraldehyde-3-phosphate dehydrogenase (GAPDH) oligonucleotide primers were constructed from published nucleotide sequence databases (Table 1). The level of GAPDH mRNA served as an internal standard for normalization of ER and PR mRNA levels. RT-PCR conditions were optimized to ensure that amplification proceeded within the linear portion of the reaction. The semi-quantitative RT-PCR amplification profile consisted of denaturation at $95^{\circ} \mathrm{C}$ for $3 \mathrm{~min}$ followed by 35 cycles of $95^{\circ} \mathrm{C}$ for $10 \mathrm{~s}$ and $65^{\circ} \mathrm{C}$ for $1 \mathrm{~min}$.

The iQ SYBR Green Supermix (QIAGEN), $0.2 \mu \mathrm{M}$ of sense and antisense oligonucleotides (ER, PR, or GAPDH), and $0.1 \mu \mathrm{g}$ cDNA were used in a final volume of $30 \mu \mathrm{l}$ for each RT-PCR reaction. The PCR products were digitally analyzed using a luminescent image analyzer (FluoImager, Beckton Dickinson) and quantified using Image Quant software (Beckton Dickinson).

\section{Statistical analysis}

The results were expressed as mean \pm standard error (SE). Statistical analyses were performed by one-way analysis of variance (ANOVA) followed by a post-hoc test (Bonferroni). Statistical significance was determined as $p<0.05$.

\section{Results}

Detection of CEPCs in peripheral blood during the menstrual cycle

The number of cEPCs in the peripheral blood obtained from subjects in the menstrual cycle was significantly 
Table 1 List of oligonucleotide primers used.

\begin{tabular}{|c|c|c|c|}
\hline GeneBank accession No. & mRNA & Sequence & $\begin{array}{l}\text { Length of DNA } \\
\text { product (bp) }\end{array}$ \\
\hline \multirow[t]{2}{*}{ NM000125 } & $E R \alpha$ & 5' AAG AGC TGC CAG GCC TGC C 3' (sense) & 168 \\
\hline & & 5' TTG GCA GCT CTC ATG TCT CC 3' (antisense) & \\
\hline \multirow[t]{2}{*}{ AB006590.1 } & ER $\beta$ & 5' TAA AAG AAG CAT TCA AGG ACA TAA T 3' (sense) & 160 \\
\hline & & 5' GCA CTT CTC TGT CTT CGT ACT ATT C 3' (antisense) & \\
\hline \multirow[t]{2}{*}{ AY382151 } & $P R A B$ & 5' TGG AAG AAA TGA CTG CAT CG 3' (sense) & 196 \\
\hline & & 5' TAG GGC TTG GCT TTC ATT TG 3' (antisense) & \\
\hline \multirow[t]{2}{*}{ AB085683 } & PR B & 5' ACA CCT TGC CTG AAC TाT CG 3' (sense) & 196 \\
\hline & & 5' CTG TCC TाT TCT GGG GGA CT 3' (antisense) & \\
\hline \multirow[t]{2}{*}{ NM002046 } & GAPDH & 5' CCA CCC ATG GCA AAT TCC ATG GCA 3' (sense) & 622 \\
\hline & & 5' TCT AGA CGG CAG GTC AGG TCC ACC 3' (antisense) & \\
\hline
\end{tabular}

increased during the luteal $(124.0 \pm 29.1 \mathrm{cells} / \mathrm{ml})$ and menstrual $(165.3 \pm 38.5 \mathrm{cells} / \mathrm{ml})$ phases compared to the follicular phase $(44.1 \pm 11.1$ cells $/ \mathrm{ml} ; p<0.05$; Figure $3 \mathrm{~A})$.

LDL/Lectin assay of cells cultured for seven days

The number of EPCs that were $\mathrm{LDL}^{+} /$lectin ${ }^{+}$derived from the peripheral blood of subjects in the luteal phase was significantly increased on the seventh day of culture $(481.2 \pm 91.2$ cells/well $)$ compared to the menstrual phase $(227.1 \pm 26.5$ cells/well; $p<0.05$; Figure $3 \mathrm{~B})$.

Effects of $E_{2} \beta$ and $P_{4}$ on the proliferation of EPCs in peripheral blood

$\mathrm{E}_{2} \beta$ or $\mathrm{P}_{4}$ significantly increased the proliferation of EPCs derived from the peripheral blood of subjects in the menstrual phase by activating the respective receptors in a dose-dependent manner (Figure 4). Receptor antagonists of ER and PR, ICI 182,780 and RU 486, respectively, reduced the proliferation of EPCs from menstrual phase. In addition, $\mathrm{P}_{4}$ did not influence the effect of $\mathrm{E}_{2} \beta$ on EPC proliferation. In contrast, the proliferation of EPCs from luteal phase was not influenced by $\mathrm{E}_{2} \beta$ or $\mathrm{P}_{4}$ (Figure 5). Moreover, these receptor antagonists did not affect the proliferation of EPCs from luteal phase.

\section{Change in ER and PR expression in CEPCs}

ER $\alpha$ mRNA expression levels in EPCs from menstrual phase were higher than ER $\beta$ mRNA as well as ER $\alpha$ mRNA in EPCs from luteal phase $(p<0.05$; Figure 6$)$. In contrast, no significant difference was observed between the expression level of total PR mRNA and isoform B mRNA in EPCs; however, the expression levels of total PR mRNA and isoform B mRNA were limited in EPCs (Figure 6).

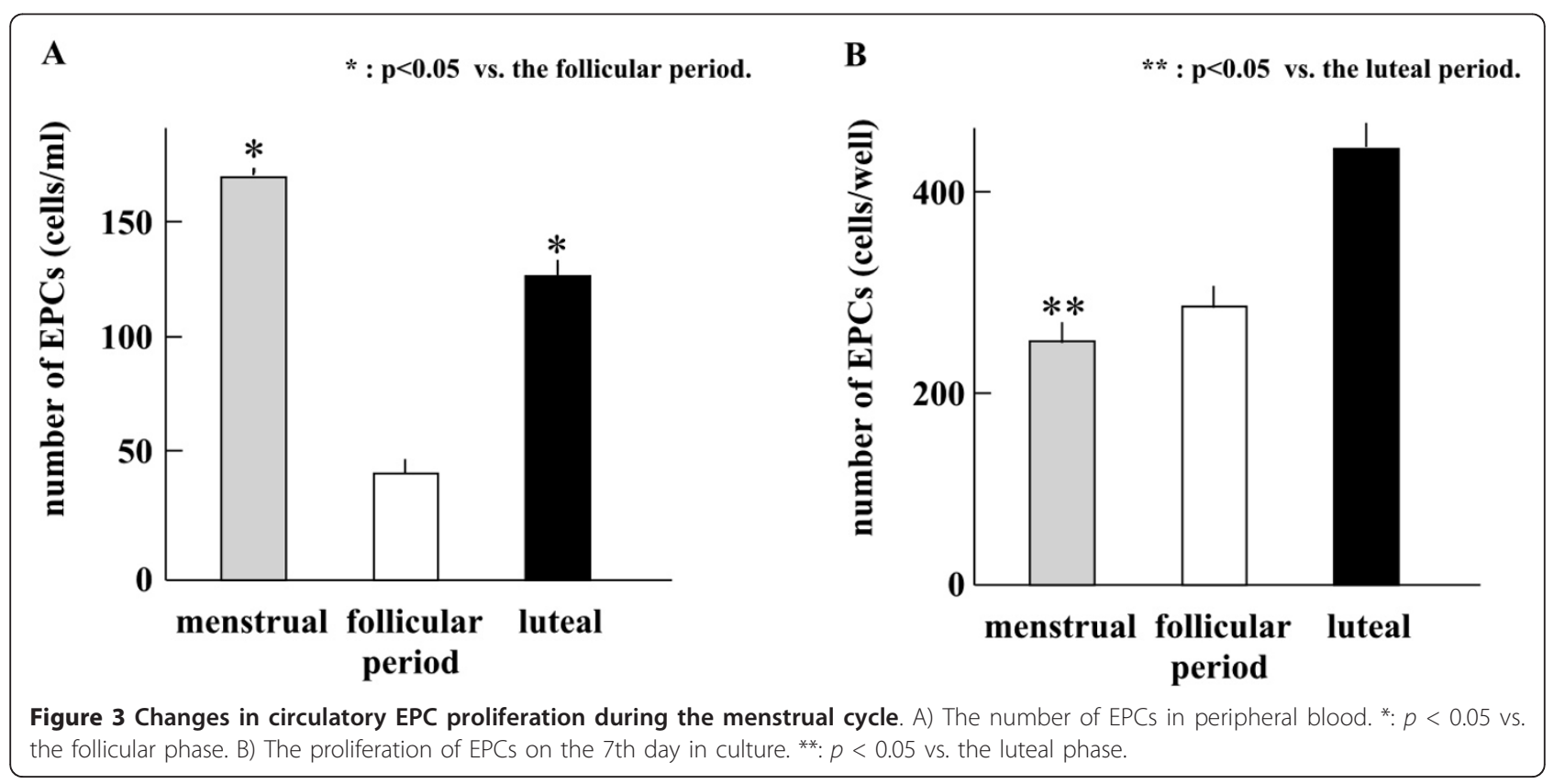




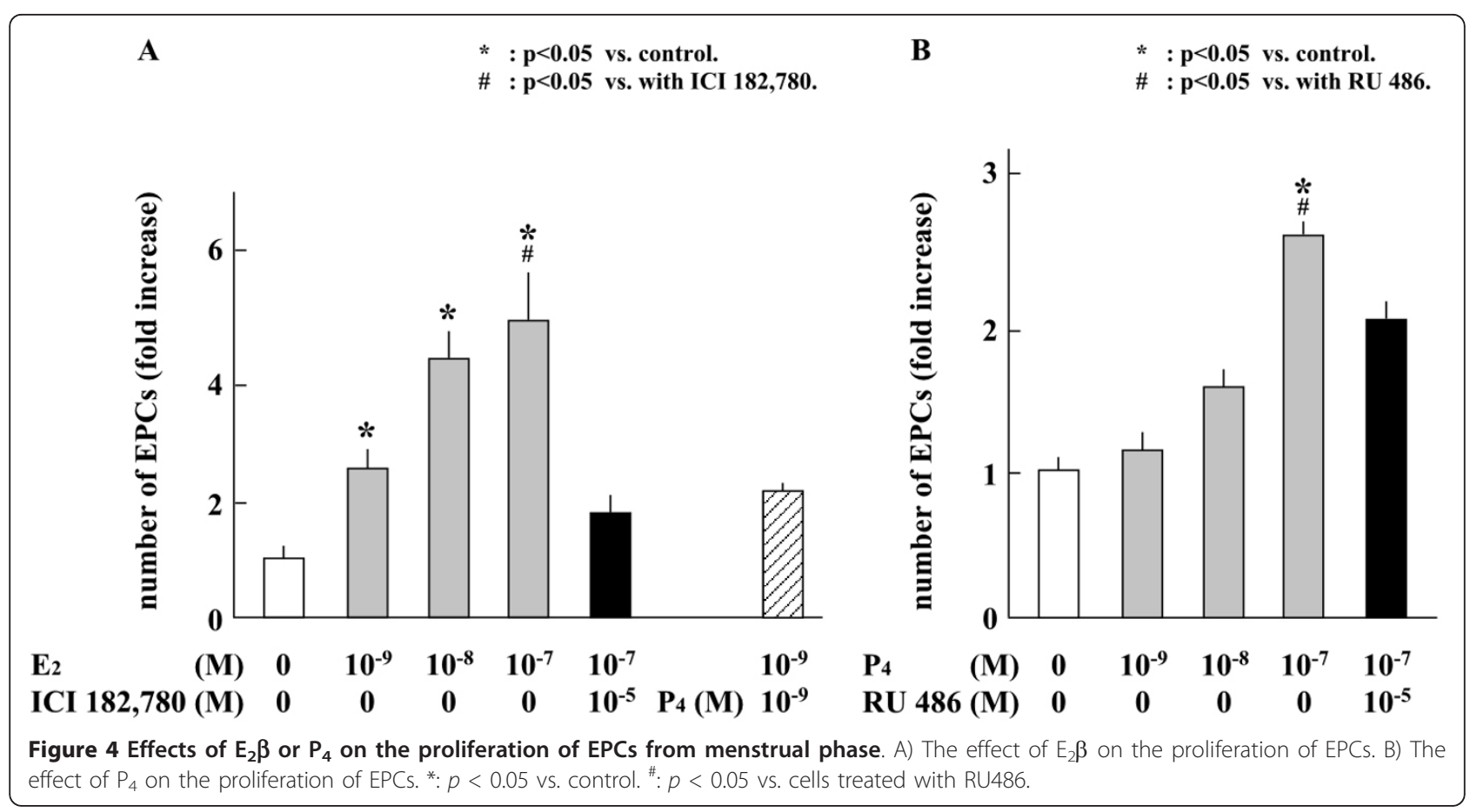

\section{Discussion}

cEPCs in the peripheral blood serve as a reserve for EC maintenance, and contribute up to $25 \%$ of ECs in newly formed vessels of ischemic lesions [25,27-32]. In addition, estrogen preserves ischemic heart function during myocardial infarction by augmenting the mobilization and incorporation of bone marrow-derived EPCs into sites of neovascularization [31]. In female reproductive organs, EPCs appear to play a crucial role in vascularization of the uterine endometrium at the site of embryo

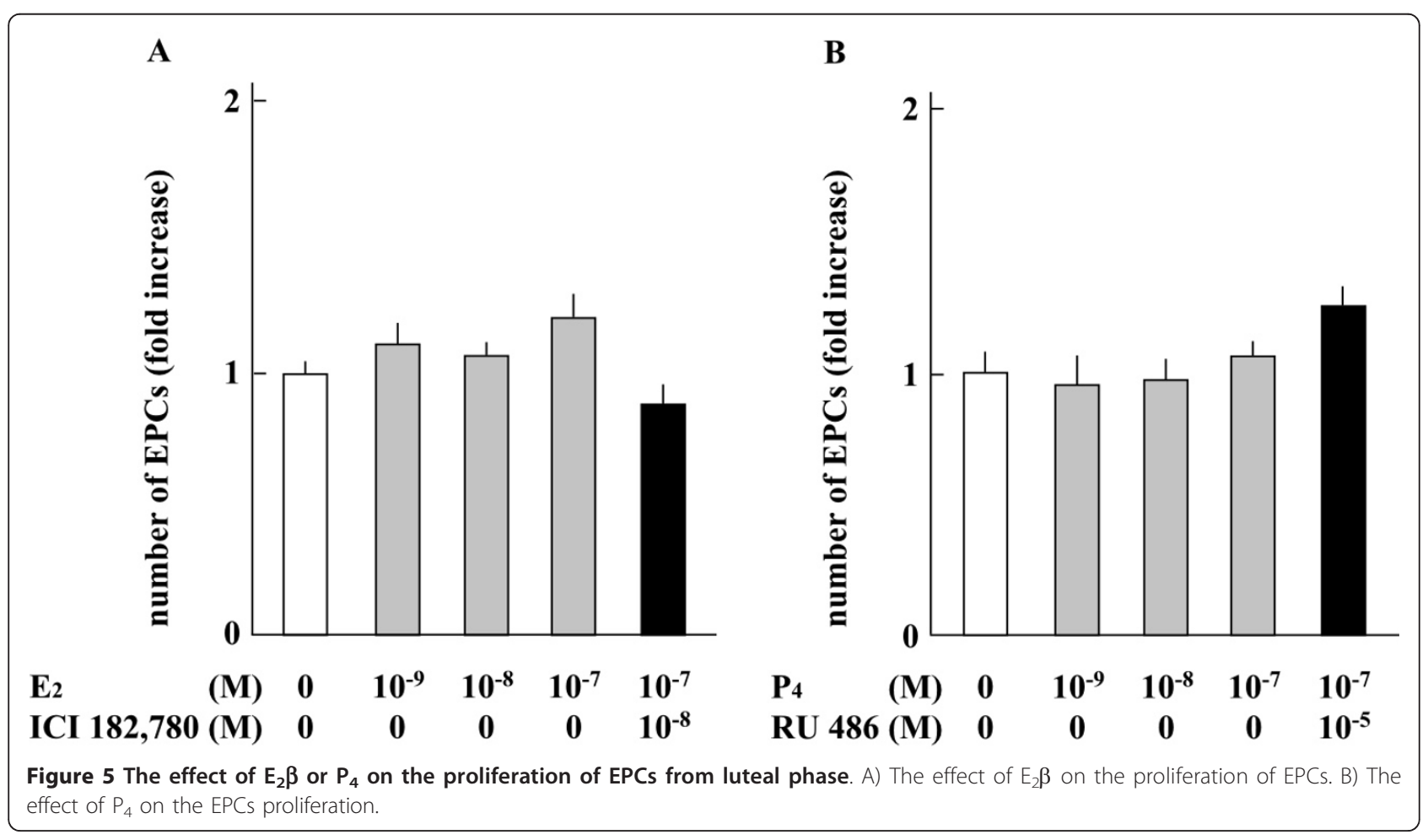




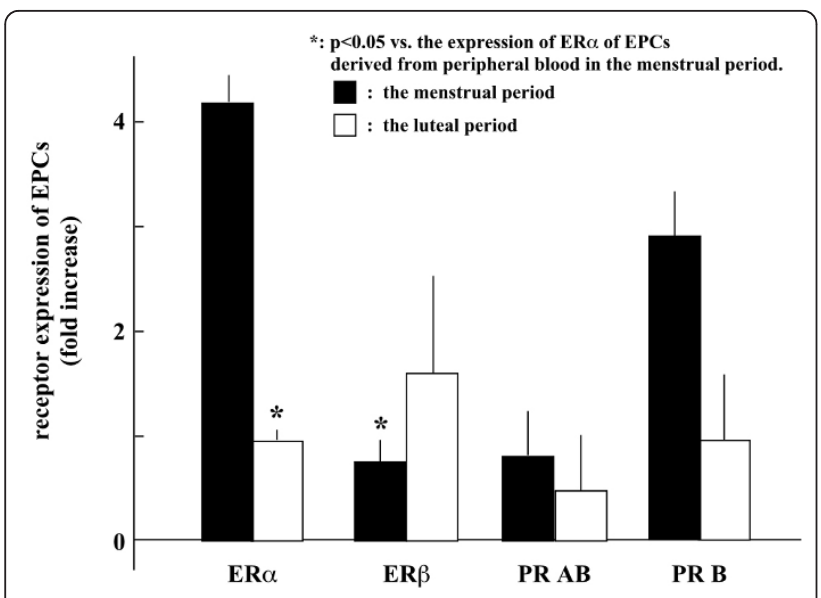

Figure 6 Expression of ER and PR mRNA in circulating EPCs. $E R \alpha, E R \beta$, and PR mRNA expression in EPCs derived from peripheral blood during the menstrual cycle (menstrual phase: solid column, luteal phase: open column). *: $p<0.05$ vs. the expression of ER $\alpha$ in EPCs from menstrual phase.

implantation and placentation [33-35]. During the menstrual cycle, the number of cEPCs in peripheral blood exhibits a cyclic change, whereby it is markedly increased during the luteal and menstrual phase, and decreased during the follicular phase. The number of cEPCs has been shown to decrease over the course of pregnancy [36]. Since EPCs were also found in the corpus luteum and uterine endometrium, the estrogenmediated increase in EPCs is thought to be involved in periodic neovascularization during the menstrual cycle $[28,37,38]$.

The differences in EPC proliferation and cEPC concentration between the menstrual and luteal phases were the most important findings of this study. We demonstrated that EPCs from menstrual phase did not proliferate after seven days in culture; however, there was a dose-dependent increase in proliferation after cells were treated with $\mathrm{E}_{2} \beta$ or $\mathrm{P}_{4}$. On the other hand, proliferation was increased in EPCs from luteal phase after seven days in culture; however, the proliferation was not influenced by addition of $\mathrm{E}_{2} \beta$ or $\mathrm{P}_{4}$. Therefore, we hypothesize that luteal EPCs may have already reached maximum stimulation in vivo and could not be activated furtherer.

Decreased proliferation of EPCs from menstrual phase suggests that this observed effect was due to decreased concentration of $\mathrm{E}_{2} \beta$ or $\mathrm{P}_{4}$ during menstruation. Therefore, the increase in proliferation was a sex steroidmediated dose-dependent increase. Since the expression of ER $\alpha$ and ER $\beta$ in EPCs was different between the menstrual and luteal phases, $\mathrm{E}_{2} \beta$-induced neovascularization may be mediated by both receptors, and the differential expression of ER $\alpha$ and ER $\beta$ indicates that they have different effects on neovascularization. ER $\alpha$ mRNA expression levels in EPCs from menstrual phase was higher than those from luteal phase as shown in Figure 6. On the other hand, the ER $\beta$ mRNA expression level in EPCs from luteal phase was higher than ER $\alpha$ expression. Since estrogen-responsive element-dependent gene transcription activities are severely impaired in EPCs obtained from ER $\alpha$-knockout mice, vascular growth is down-regulated in ER $\alpha$-knockout EPCs $[39,40]$, and epithelial cell proliferation can be reduced through the activation of ER $\beta$ [30], the increased expression of ER $\alpha$ may at least partially explain the increase in $E_{2} \beta$-induced proliferation of EPCs derived from subjects in the menstrual phase. However, the roles of ER $\alpha$ and ER $\beta$ in EPC biology during the menstrual cycle will require further elucidation.

The cEPC concentration was lowest in the follicular phase, and EPC proliferation in the cultures was not different compared to the other cultures. It has been well established that the serum concentration of $E_{2}$ and VEGF is very low during the early follicular phase $[12,41]$. Therefore, it is possible that decreased VEGF and $E_{2}$ expression during the follicular phase could reduce the recruitment of cells from bone marrow into blood, since VEGF can induce the recruitment of EPCs from bone marrow [42]. These observations suggest that the initial priming of the ovarian hormone is required for EPC proliferation during the menstrual cycle.

Estrogen also stimulates extensive placental neovascularization through the up-regulation of angiogenic factors in the uterus during pregnancy [43], and the number of cEPCs peaks from luteal phase through the 1 st trimester [44]. This finding is consistent with the fact that vasculogenesis peaks during embryogenesis $[35,45]$. On the other hand, estrogen is reduced after menopause, which leads to the depletion of EPCs [38], and estrogen replacement therapy can delay the onset of senescence in bone marrow-derived EPCs [46]. Therefore, estrogen is critical in promoting angiogenesis and vasculogenesis in female reproductive organs.

\section{Conclusion}

In the female reproductive system, vasculogenesis is a recurring phenomenon controlled by the cyclical development of a transient structure and the cyclical repair of damaged tissue by $\mathrm{E}_{2}$ and $\mathrm{P}_{4}$ during the menstrual cycle. It is hypothesized that neovascularization is regulated by the crosstalk between these hormones in utero during the ovarian cycle and pregnancy in preparation for implantation and the maintenance of pregnancy. The findings described in this study provide evidence that the physiologic cycle of estrogen regulates EPC proliferation through the alternating balance of ER mRNA expression. 


\section{Acknowledgements}

This work was supported, in part by the Grant-in-Aid for Japan Scientific Research from the Ministry of Education, Culture, Sports, Science and Technology (18591803).

\section{Authors' contributions}

YM collected all samples, carried out the molecular genetic studies, participated in the sequence alignment, and drafted the manuscript. KM carried out EPC isolation, LDL/lectin assay, and FACS analysis. KM also participated in the design of the study, performed the statistical analysis, and helped to review the manuscript. All authors read and approved the final manuscript.

\section{Competing interests}

The authors declare that they have no competing interests.

Received: 7 September 2011 Accepted: 17 January 2012

Published: 17 January 2012

\section{References}

1. Magness RR, Zheng J: Maternal Cardiovascular Alterations During Pregnancy. In Pediatrics and Perinatology. The Scientific Basis.. 2 edition. Edited by: Gluckman PD, Heymann MA. Arnold Publishing, London; 1996:762-772.

2. Magness RR: Maternal cardiovascular and other physiologic responses to the endocrinology of pregnancy. In Endocrinology of Pregnancy. Volume 18. Fuller Bazer, Humana Press Inc, Totowa NJ; 1998:507-539.

3. Perrot-Applanat M, Deng M, Fernandez H, Lelaidier C, Meduri G, Bouchard P: Immunohistochemical localization of estradiol and progesterone receptors in human uterus throughout pregnancy: expression in endometrial blood vessels. J Clin Endocrinol Metab 1994, 78:216-224.

4. Jabbour HN, Kelly RW, Fraser HM, Critchley HO: Endocrine regulation of menstruation. Endocr Rev 2006, 27:17-46.

5. Mints M, Jansson M, Sadeghi B, Westgren M, Uzunel M, Hassan M, Palmblad J: Endometrial endothelial cells are derived from donor stem cells in a bone marrow transplant recipient. Hum Reprod 2008, 23:139-143.

6. Risau W, Flamme I: Vasculogenesis. Annu Rev Cell Dev Biol 1995, 11:73-91

7. Murayama T, Tepper O, Silver M, Ma H, Losordo DW, Isner JM, Asahara T, Kalka C: Determination of bone marrow-derived endothelial progenitor cell significance in angiogenic growth factor-induced neovascularization in vivo. Exp Hematol 2002, 30:967-972

8. Asahara T, Masuda H, Takahashi T, Kalka C, Pastore C, Silver M, Kearney M, Magner M, Isner JM: Bone marrow origin of endothelial progenitor cells responsible for postnatal vasculogenesis in physiological and pathological neovascularization. Circ Res 1999, 85:221-228.

9. Perrot-Applanat M, Ancelin M, Buteau-Lozano H, Meduri G, Bausero P: Ovarian steroids in endometrial angiogenesis. Steroids 2000, 65:599-603.

10. Hyder SM, Stancel GM: Regulation of angiogenic growth factors in the female reproductive tract by estrogens and progestins. Mol Endocrinol 1999, 13:806-811.

11. Carr BR, Wilson JD: Disorders of the ovary and the female reproductive tract. In Harrison's Principles of Internal Medicine.. 11 edition. Edited by: Braunwald E, Isselbacher KJ, Petersdorf RG, Nilson JD, Martin JB, Fauci AS. New York: McGraw-Hill; 1987:1818-1837.

12. Baird DT, Fraser IS: Blood production and ovarian secretion rates of esuadiol-17 $\beta$ and estrone in women throughout the menstrual cycle. J Clin Endocrinol Metab 1974, 38:1009-1017.

13. King AG, Zheng J, Bird IM, Magness RR: Estrogen receptor (ER) - $a$ and ER$\beta$ stimulation increases vascular endothelial growth factor secretion by ovine uterine artery endothelial cells. 35th Annual Meeting of the Society for the Study of Reproduction 2002.

14. Byers MJ, Chen DB, Phernetton TM, Bird IM, Magness RR: Endothelial Estrogen Receptor $\alpha$ and $\beta$ Expression and Steroid Regulation in Ovine Uterine Arteries. 48th Annual Meeting of the Society for Gynecologic Investigation 2001

15. Chen Z, Yuhanna IS, Galcheva-Gargova Z, Karas RH, Mendelsohn ME, Shaul PW: Estrogen receptor alpha mediates the nongenomic activation of endothelial nitric oxide synthase by estrogen. J Clin Invest 1999, 103:401-406.
16. Morales DE, McGowan KA, Grant DS, Maheshwari S, Bhartiya D, Cid MC, Kleinman HK, Schnaper HW: Estrogen promotes angiogenic activity in human umbilical vein endothelial cells in vitro and in a murine model. Circulation 1995, 91:755-763.

17. Shekhar MPV, Werdell J, Tait L: Interaction with endothelial cells is a prerequisite for branching ductal-alveolar morphogenesis and hyperplasia of preneoplastic human breast epithelial cells: regulation by estrogen. Cancer Res 2000, 60:439-449.

18. Ruifrok WP, de Boer RA, Iwakura A, Silver M, Kusano K, Tio RA, Losordo DW: Estradiol-induced, endothelial progenitor cell-mediated neovascularization in male mice with hind-limb ischemia. Vasc Med 2009, 14:29-36.

19. Ma W, Tan J, Matsumoto H, Robert B, Abrahamson DR, Das SK, Dey SK: Adult tissue angiogenesis: Evidence for negative regulation by estrogen in the uterus. Mol Endocrinol 2001, 15:1983-1992.

20. Rupnow HL, Phernetton TM, Shaw CE, Modrick ML, Bird IM, Magness RR. Endothelial vasodilator production by uterine and systemic arteries. VII. Estrogen and progesterone effects on eNOS. Am J Physiol Heart Circ Physiol 2001, 280:H1699-H1705.

21. Levine RL, Chen S-J, Durand J, Chen Y-F, Oparil S: Medroxyprogesterone attenuates estrogen-mediated inhibition of neointima formation after balloon injury of the rat carotid artery. Circulation 1996, 94:2221-2227.

22. McDonnell DP, Clemm DL, Hermann T, Goldman ME, Pike JW: Analysis of estrogen receptor function in vitro reveals three distinct classes of antiestrogens. Mol Endocrinol 1995, 9:659-669.

23. Resnik R, Brink GW, Plumer MH: The effect of progesterone on estrogeninduced uterine blood flow. Am J Obstet Gynecol 1977, 128:251-254.

24. Magness RR, Phernetton TM, Zheng J: Systemic and uterine blood flow distribution during prolonged infusion of $17 \beta$-estradiol. Am J Physiol 1998, 275(Heart Circ Physiol):H731-H743.

25. Kalka C, Masuda H, Takahashi T, Kalka-Moll WM, Silver M, Kearney M, Li T, Isner JM, Asahara T: Transplantation of ex vivo expanded endothelial progenitor cells for therapeutic neovascularization. Proc Natl Acad Sci USA 2000, 28:3422-3427.

26. Pan $\mathrm{Q}$, Luo X, Toloubeydokhti T, Chegini N: The expression profile of micro-RNA in endometrium and endometriosis and the influence of ovarian steroids on their expression. Mol Hum Reprod 2007, 13:797-806.

27. Peichev M, Naiyer A, Pereira D, Zhu Z, Lane WJ, Williams M, Oz MC, Hicklin DJ, Witte L, Moore MA, Rafii S: Expression of VEGFR-2 and AC133 by circulating human CD34+ cells identifies a population of functional endothelial precursors. Blood 2000, 95:952-958.

28. Asahara T, Masuda H, Takahashi T, Kalka C, Pastore C, Silver M, Kearne M, Magner M, Isner JM: Bone marrow origin of endothelial progenitor cells responsible for postnatal vasculogenesis in physiological and pathological neovascularization. Circ Res 1999, 85:221-228.

29. Murayama T, Tepper O, Silver M, Ma H, Losordo DW, Isner JM, Asahara T, Kalka C: Determination of bone marrow-derived endothelial progenitor cell significance in angiogenic growth factor-induced neovascularization in vivo. Exp Hematol 2002, 30:967-972.

30. Orlic D, Kajstura J, Chimenti S, Jakoniuk I, Anderson SM, Li B, Pickel J, McKay R, Nadal-Ginard B, Bodine DM, Leri A, Anversa P: Bone marrow cells regenerate infarcted myocardium. Nature 2001, 410:701-705.

31. Asahara T, Masuda H, Takahashi T, Kalka C, Pastore C, Silver M, Kearne M, Magner M, Isner JM: Bone marrow origin of endothelial progenitor cells responsible for postnatal vasculogenesis in physiological and pathological neovascularization. Circ Res 1999, 85:221-228.

32. Iwakura A, Luedemann C, Shastry S, Hanley A, Kearney M, Aikawa R, Isner JM, Asahara T, Losordo DW: Estrogen-mediated, endothelial nitric oxide synthase-dependent mobilization of bone marrow-derived endothelial progenitor cells contributes to reendothelialization after arterial injury. Circulation 2003, 108:3115-3121.

33. Taylor A, Al-Azzawi F: Immunolocalisation of oestrogen receptor beta in human tissues. J Mol Endocrinol 2000, 24:145-155.

34. Gussin H, Bischoff F, Hoffman R, Elias S: Endothelial precursor cells in the peripheral blood of pregnant women. J Soc Gynecol Invest 2000, 9:357-361.

35. Ottersbach K, Dzierzak E: The murine placenta contains hematopoietic stem cells within the vascular labyrinth region. Dev Cell 2005, 8:377-387.

36. Matsubara K, Abe E, Matsubara Y, Kameda K, Ito M: Circulating endothelial progenitor cells during normal pregnancy and pre-eclampsia. ARJI 2006 56:1-7. 
37. Lemieux C, Cloutier I, Tanguay JF: Menstrual cycle influences endothelial progenitor cell regulation: a link to gender differences in vascular protection? Int J Cardiol 2009, 136:200-210.

38. Iwakura A, Shastry S, Luedemann C, Hamada H, Kawamoto A, Kishore R, Zhu Y, Qin G, Silver M, Thorne T, Eaton L, Masuda H, Asahara T,

Losordo DW: Estradiol enhances recovery after myocardial infarction by augmenting incorporation of bone marrow-derived endothelial progenitor cells into sites of ischemia-induced neovascularization via endothelial nitric oxide synthase-mediated activation of matrix metalloproteinase-9. Circulation 2006, 113:1605-1614.

39. Hamada H, Kim MK, Iwakura A, Ii M, Thorne T, Qin G, Asai J, Tsutsumi Y, Sekiguchi H, Silver M, Wecker A, Bord E, Zhu Y, Kishore R, Losordo DW: Estrogen receptors alpha and beta mediate contribution of bone marrow-derived endothelial progenitor cells to functional recovery after myocardial infarction. Circulation 2006, 114:2261-2270.

40. Strehlow K, Werner N, Berweiler J, Link A, Dirnagl U, Priller J, Laufs K, Ghaeni L, Milosevic M, Böhm M, Nickenig G: Estrogen increases bone marrow-derived endothelial progenitor cell production and diminishes neointima formation. Circulation 2003, 107:3059-3065.

41. Nakamura J, Lu Q, Aberdeen G, Albrecht E, Brodie A: The effect of estrogen on aromatase and vascular endothelial growth factor messenger ribonucleic acid in the normal nonhuman primate mammary gland. J Clin Endocrinol Metab 1999, 84:1432-1437.

42. Dong L, Kang L, Ding L, Chen Q, Bai J, Gu R, Li L, Xu B: Insulin modulates ischemia-induced endothelial progenitor cell mobilization and neovascularization in diabetic mice. Microvasc Res 2011, 82:227-236.

43. Albrecht E, Robb V, Pepe G: Regulation of placental vascular endothelial growth/permeability factor expression and angiogenesis by estrogen during early baboon pregnancy. J Clin Endocrinol Metab 2004, 89:5803-5809.

44. Carnegie JA, Robertson HA: Conjugated and unconjugated estrogens in fetal and maternal fluids of the pregnant ewe: a possible role for estrone sulfate during early pregnancy. Biol Reprod 1978, 19:202-211.

45. Flamme I, Risau W: Induction of vasculogenesis and hematopoiesis in vitro. Development 1992, 116:435-459.

46. Imanishi T, Kobayashi K, Hano T, Nishio I: Effect of estrogen on differentiation and senescence in endothelial progenitor cells derived from bone marrow in spontaneously hypertensive rats. Hypertens Res 2005, 28:763-772.

doi:10.1186/1477-7827-10-2

Cite this article as: Matsubara and Matsubara: Estrogen and progesterone play pivotal roles in endothelial progenitor cell proliferation. Reproductive Biology and Endocrinology 2012 10:2.

\section{Submit your next manuscript to BioMed Central and take full advantage of:}

- Convenient online submission

- Thorough peer review

- No space constraints or color figure charges

- Immediate publication on acceptance

- Inclusion in PubMed, CAS, Scopus and Google Scholar

- Research which is freely available for redistribution

Submit your manuscript at www.biomedcentral.com/submit
Biomed Central 